\title{
Penyuluhan Hukum “Meningkatkan Kesadaran Pemahaman Hukum Lingkungan Kepada Masyarakat (Dalam Rangka Memperingati Hari Cinta Puspa dan Satwa)"
}

\author{
Eza Aulia', Phoenna Ath Thariq ${ }^{2}$, Rachmatika lestari ${ }^{3}$, Rahmad Jhoanda ${ }^{4}$ \\ 1,2,3,4 Jurusan Ilmu Hukum, Universitas Teuku Umar \\ Email: ezaaulia@utu.ac.id \\ Email: phoennaaththariq@utu.ac.id \\ Email: rachmatikalestari@utu.ac.id \\ Email: rahmadjhoanda@utu.ac.id
}

Submitted: 05 Desember 2019 Revised: 29 Desember 2019 Accepted: 31 Desember 2019

\begin{abstract}
The phenomenon of right of ownership disputes is a big problem that exists in the civil society of Nagan Raya Regency. Especially in the Rawa Tripa area at Suka Makmur District, another problem is related to the lack of community understanding of peat area protection and land clearing methods which are carried out using burning patterns. Based on observations also found a number of cases of land disputes between civil society and corporations in the Rawa Tripa area. The implementation of this community service is in the form of legal counseling which is carried out face-to-face by delivering material related to the theme of community service. The results and benefits obtained from the implementation of this legal counseling are able to provide understanding and legal awareness to the community related to rights of ownership, duties and functions of the civil society in preserving the environment, as well as education related to the constitutional rights of citizens in the environment and natural resources sector.
\end{abstract}

Keywords: Legal Education, Society, Living Environment

\begin{abstract}
Abstrak
Fenomena sengketa hak milik merupakan persoalan besar yang ada ditengah-tengah masyarakat Kabupaten Nagan Raya Khususnya di kawasan Rawa Tripa Kecamatan Suka Makmur, persoalan lainnya adalah terkait minimnya pemahaman masyarakat tentang perlindungan kawasan gambut dan metode pembukaan lahan yang dilakukan dengan menggunakan pola pembakaran. Berdasarkan hasil pengamatan ditemukan pula sejumlah kasus sengketa lahan antara masyarakat dengan korporasi di dalam kawasan Rawa Tripa. Pelaksanaan pengabdian ini berupa penyuluhan hukum yang dilaksanakan secara tatap muka dengan menyampaikan materi yang berkaitan dengan tema pengabdian. Hasil dan manfaat yang diperoleh dari pelaksanaan penyuluhan hukum ini ialah mampu memberikan pemahaman dan kesadaran hukum kepada masyarakat terkait dengan hak milik, tugas dan fungsi masyarakat dalam menjaga kelestarian lingkungan hidup, serta edukasi terkait dengan hak konstitusional warga negara di sektor lingkungan dan sumber daya alam.
\end{abstract}

Kata Kunci: Penyuluhan Hukum, Masyarakat, Lingkungan Hidup

\section{PENDAHULUAN}

Kesadaran hukum diartikan kesadaran atau nilai-nilai yang terdapat yang terdapat di dalam diri manusia tentang hukum yang ada atau tentang hukum yang diharapkan ada. Penekanannya adalah terhadap nilai-nilai dan fungsi hukum, bukan melainkan penilaian hukum terhadap kejadiankejadian yang konkrit di dalam masyarakat (Soekanto, 1982).

Lawrence Friedman mengartikan kesadaran hukum sebagai bagian dari "kultur hukum" yang merupakan nilai-nilai, sikap-sikap 
yang mempengaruhi bekerjanya hukum (Warasih, 2005).

Kesadaran hukum pada masyarakat bukan merupakan proses yang sekali jadi, namun merupakan suatu rangakain proses yang terjadi tahap demi tahap yang dapat dijabarkan sebagai berikut: 1 . Tahap pengetahuan hukum; 2. Tahap pemahaman hukum; 3. Tahap sikap hukum (legal attitude); 4. tahap pola perilaku hukum (Fuady, 2007).

Pada tahap pengetahuan hukum, dapat dijelaskan merupakan pengetahuan seseorang berkenaan dengan perilaku tertentu yang diatur dalam hukum tertulis, yaitu berkenaan dengan apa yang boleh dan tidak diperbolehkan. Tahap pemahaman hukum adalah bahwa sejumlah informasi yang dimiliki seseorang mengenai isi dari aturan hukum tertulis, yaitu berkaitan dengan isi, tujuan, dan manfaat dari peraturan.

Tahap selanjutnya yaitu tahap sikap hukum (legal attitude) adalah merupakan suatu kecenderungan untuk menerima ataupun menolak hukum dikarenakan adanya penghargaan atau kesadaran bahwa hukum itu memilki manfaat ataupun tidak bagi kehidupan manusia. Tahap pola perilaku hukum memiliki maksud tentang keberlakuan atau tidaknya suatu aturan hukum dalam masyarakat, terkait pula sejauhmana masyarakat mematuhi dan mentaati, serta sebaliknya.

Kesadaran hukum berkaitan erat dengan kepatuhan hukum. Namun yang membedakan ke dua hal tersebut adalah bahwa di dalam kepatuhan hukum terdapat rasa takut akan sanksi, sedangkan kesadaran hukum tidak menekankan pada suatu paksaan dan sanksi terhadap pelanggaran yang dilakukan akan tetapi lahir dari sikap batin yang tumbuh dari pemahamanpemahaman dasar akan pentingnya suatu keteraturan di dalam masyarakat.

Masyarakat yang mendiami kawasan Rawa Tripa Kecamatan Suka Makmur Kabupaten Nagan Raya merupakan masyarakat tinggal ditengah-tengah kawasan gambut, di mana mayoritas masyarakat merupakan petani sawit yang menggantungkan hidupnya dari hasil perkebunan.

Terjadi konflik yang berkepanjangan terkait dengan kepemilikan lahan yang menjadi sengketa antara masyarakat yang tinggal di kawasan tersebut dengan korporasi/perusahaan yang mendapatkan hak guna usaha di dalam kawasan tersebut.

Konflik saling klaim antara masyarakat dan korporasi ini menjadi masalah yang sangat rumit dan pelik, di mana hak guna usaha yang didapatkan oleh korporasi/perusahaan menyerobot lahan yang telah didiami dan 
digarap oleh masyarakat berdasarkan hak ulayat.

Aktivitas korporasi dalam hal menjalankan usahanya atas dasar hak guna usaha memberikan dampak yang merugikan masyarakat selain dari konflik klaim atas lahan pertanian sawit. Aktivitas atau perilaku yang dilakukan oleh korporasi dalam menjalankan usahanya menimbulkan kerusakan terhadap lingkungan hidup yang dampaknya dirasakan langsung oleh masyarakat setempat.

Seperti halnya pembukaan lahan yang dilakukan dengan cara melawan hukum yaitu dengan menerapkan metode pembakaran lahan menyebabkan terjadinya polusi dalam skala yang besar, mengakibatkan pula rusaknya ekosistem, dan terganggunya habitat satwa. Kemudian perkebunan sawit yang dibangun dengan mengenyampingkan kelestarian lingkungan memicu terjadinya berbagai macam bencana alam, seperti contoh terkecil kawasan sekitar menjadi kawasan yang rawan akan banjir dan diproyeksikan di masa yang akan datang akan terjadi kekeringan, serta beralihanya fungsi hutan gambut sebelumnya yang menjadi penyimpan air dan produsen oksigen.

Secara ringkas tergambar bahwa aktivitas korporasi dalam menjalankan usahanya mengganggu kesejahteraan masyarakat setempat, di mana ketentraman dan kenyamanan masyarakat yang menjadi hak konstitusional dan merupakan hak dasar yang harus dipenuhi dan tidak dapat untuk dikurang-kurangi terganggu atas aktivitas tersebut.

Segala resiko yang telah diutarakan tersebut akan bersinggungan langsung dengan masayarakat setempat, di mana korban langsung atas tindakan yang tidak bertanggungjawab tersebut, efeknya akan secara langsung dirasakan oleh masyarakat.

Kerusakan lingkungan yang timbul atas aktivitas koorporasi yang dilakukan dengan cara melawan hukum harus dapat dipertanggungjawabkan dengan berbagai cara, yang dalam hal ini ditekankan melalui cara-cara hukum yang memberikan sanksi yang tegas terhadap kerusakan lingkungan yang dilakukan, kemudian perintah untuk mengembalikan fungsi lingkungan dan ekosistemnya dengan cara merehabilitasi lingkungan hidup sehingga kemanfaatan lingkungan hidup akan dapat terus dirasakan di masa yang akan datang oleh generasi mendatang, selain itu masyarakat selaku pihak yang langsung merasakan dampak dari kerusakan lingkungan harus mendapatkan ganti rugi atas kerugian yang selama ini diderita.

Berangkat dari berbagai isu terkait permasalahan lingkungan 
hidup dan konflik lahan yang dialami oleh masyarakat di kawasan Rawa Tripa Kecamatan Suka Makmur Kabupaten Nagan Raya. Maka terhadap masyarakat tersebut menjadi objek sasaran utama dilakukannya penyuluhan hukum sebagai agenda pengabdian.

Penyuluhan hukum adalah jenis bantuan hukum tertentu, bersifat preventif, merupakan kegiatan yang dikerjakan secara sengaja dan terencana untuk memberikan bantuan hukum kepada pihak-pihak tertentu melalui komunikasi, agar pihak-pihak tersebut mampu untuk mengambil keputusan (Soekanto., 1986).

Menurut pendapat Soejono Soekanto, tujuan utama penyuluhan hukum adalah agar warga negara memahami hukum yang berlaku, sehingga hukum tersebut melembaga dan bahkan menjiwai warga masyarakat yang bersangkutan (Soekanto., 1986).

Menurut (Sudjana, 2016) Bahwa sasaran dari dilakukannya penyuluhan hukum antara lain adalah sebagai berikut:

1) Melakukan edukasi dan pembudayaan hukum secara umum ditujukan kepada seluruh masyarakat. Bahwa banyaknya pelanggaran hukum yang terjadi dikarena-kan lemahnya diseminasi dan penyuluhan hukum yang merupakan bagian dari tanggungjawab penyelenggara negara dan aparat penegak hukum.

2) Meningkatkan penggunaan media komunikasi yang lebih modern dalam pelaksanaan penyuluhan hukum yang dapat menunjang percepatan penyebaran, pengetahuan, pemahaman, dan penghayatan hukum.

3) Meningkatkan koordinasi dalam melaksanakan sosialisasi hukum dengan memanfaatkan partisipasi masyarakat aktif, media elektronik amupun non elektronik dan juga dengan memanfaatkan teknologi informasi.

4) Meningkatkan dan memperkaya metode pengembangan dan penyuluhan hukum untuk meningkatkan kesadaran hukum masyarakat dan hak asasi manusia secara terus menerus.

5) Memanfaatkan segala bentuk kampanye hukum baik langsung maupun tidak lang- sung, dengan menciptakan slogan-slogan hukum yang melekat di hati masyarakat sehingga masyarakat tergerak dengan sendi- rinya untuk meningkatkan budaya hukum.

6) Meningkatkan profesionalisme dan kemam- puan tenaga penyuluh hukum baik dari substansi hukum, sosiologi serta pengenalan perilaku masyarakat setempat, sehingga komunikasi dalam menyampaikan materi 
hukum yang disuluh dapat lebih tepat, dipahami, diterima dengan baik oleh masyarakat.

7) Melalui kemampuan dan profesionalisme dalam melakukan penyuluhan hukum, agar pesan yang disampaikan kepada masyarakat tercapai dan diterima secara baik, maka harus melakukan langkah cerdas dalam penyuluhan hukum dengan memberikan rasa percaya masyarakat kepada tenaga penyuluh.

8) Law enforcement harus dibarengi dengan upaya preventif dalam bentuk sosialisasi produk-produk hukum karena hukum juga harus memberikan perlindungan kepada rakyat untuk memperoleh keadilan bukan untuk menyengsarakan. Oleh karena itu penyuluhan hukum harus mendapatkan perhatian yang serius.

Penyuluhan ini dilaksanakan berdasarkan suatu urgensitas akan kebutuhan hukum masyarakat yang terpetakan dari masalah-masalah hukum berkenaan dengan lingkungan hidup yang terjadi di lapangan.

Adapun materi-materi yang disampaikan dalam penyuluhan tersebut antara lain memuat: kajian lingkungan hidup berdasarkan deklarasi internasional Stockholm, kedaulatan lingkungan hidup dalam negara demokrasi Indonesia, peranggungjawaban pemerintah dalam rehabilitasi lingkungan hidup dalam tinjauan hukum tata negara, partisipasi masyarakat dalam penyelamatan lingkungan hidup, tanggungjawab keperdataan bagi perusahaan pelaku perusak lingkungan hidup, izin eksplorasi dan eksploitasi ditinjau dari peraturan perundang-undangan, serta peran Dinas Lingkungan Hidup dalam proses penyelesaian sengketa lingkungan hidup di Kabupaten Nagan Raya.

Tujuan dari penyuluhan hukum ini adalah memberikan pemahaman dasar kepada masyarakat berkenaan dengan hak-hak dasar masyarakat terkait lingkungan hidup, tugas dan fungsi masyarakat dalam mempertahankan kelestarian lingkungan hidup, upaya-upaya yang dapat dilakukan dalam menangani persoalan lingkungan hidup, penguatan kapasitas pemahaman hukum masyarakat meyangkut persoalan sengketa lahan antara hak milik masyarakat berdasarkan ulayat dengan hak guna usaha yang dimiliki oleh korporasi/perusahaan.

Adapun manfaat dari peyuluhan hukum ini adalah untuk meningkatkan pemahaman dasar masyarakat terkait hak-hak dasar berkenaan dengan lingkungan yang dijamin oleh regulasi yang ada, memberikan pemahaman dan kesadaran akan tugas serta fungsi 
masyarakat dalam mempertahankan kelestarian lingkungan hidup, melakukan penguatan kapasitas pemahaman masyarakat menyangkut persoalan sengketa lahan antara masyarakat dengan korporasi.

Penyuluhan hukum ini direncanakan adalah merupakan upaya awal untuk membantu segala permasalahan hukum masyarakat di kawasan Rawa Tripa, di mana rencana kedepannya akan diagendakan kembali kegiatankegiatan untuk menindak lanjuti hasil dari penyuluhan hukum yang telah dilakukan. Sehingga dengan adanya kegiatan-kegiatan seperti ini dapat membantu memberikan solusi hukum serta mengawal penyelesaian kasus sengketa lahan antara masyarakat dengan korporasi di kawasaran Rawa Tripa.

\section{METODE PELAKSANAAN}

Adapun metode pelaksanaan kegiatan pengabdian masyarakat diawali dengan tahapan menyusun persiapan dalam penyelenggaraan penyuluhan hukum berlangsung secara tertib. Adapun persiapan yang perlu dilakukan adalah sebagai berkut:

Melakukan studi pustaka tentang upaya meningkatkan kesadaran masyarakat terhadap pemahaman hukum lingkungan yang masih jarang diketahui oleh sebagian besar masyarakat.
Mempersiapkan perlengkapan penunjang acara penyuluhan hukum. Mengatur tempat serta pengecekan terkait fasilitas penunjang acara penyuluhan hukum yang dilakukan.

Membuat schedule acara, mengundang pihak-pihak terkait dengan isu yang akan dibahas dalam penyuluhan hukum yang dilakukan. Selanjutnya mempersiapkan materi yang akan dipresentasikan dalam acara penyuluhan hukum yang dilakukan.

Penyuluhan hukum dengan tema "meningkatkan kesadaran pemahaman hukum lingkungan kepada masyarakat (dalam rangka peringatan hari cipta puspa dan satwa) dilakukan pada tanggal 6 November 2019 bertempat di aula Sekertariat Daerah Kabupaten Nagan Raya.

Pelaksanaan kegiatan penyuluhan ini dihadiri oleh mukim di kawasan Rawa Tripa sebanyak 2 (dua) orang, keucik gampong disekitar kawasan rawa tripa sebanyak 5 (lima) orang, masyarakat disekitar kawasan sebanyak 25 (dua puluh lima) orang, tokoh masyarakat adat Nagan Raya sebanyak 2 (dua) orang, staf Kecamatan Suka Makmur sebanyak 2 (dua) orang, lembaga pemerhati lingkungan sebanyak 3 (tiga) orang, staf Kementrian Lingkungan Hidup 1 (satu) orang, Polisi Hutan sebanyak 1 (satu) orang, perwakilan organisasi kemasyarakatan sebanyak 2 (dua) 
orang, mahasiswa sebanyak 8 delapan) orang dan akademisi prodi Ilmu Hukum FISIP UTU sebanyak 6 (enam) orang.

Kegiatan penyluhan hukum ini dilakukan dengan menggunakan 3 (tiga) metode penyuluhan antara lain: penyuluhan hukum yang dilakukan dengan mekanisme ceramah atau diskusi yang disampaikan oleh pemateri dan dibuka sesi tanyajawab, metode selanjutnya adalah melalui forum grup diskusi (FGD), FGD dilakukan dengan tujuan agar memahami dan mengetahui pentingnya kesadaran hukum dalam mendata rencana tindak lanjut dari penyuluhan yang dilakukan, kemudian metode lainnya merupakan pendampingan langsung terkait permasalahan hukum yang dialami oleh masyarakat, metode dilakukan dengan menggelar panel di mana akademisi akan memberikan konsultasi hukum kepada pihak masyarakat.

Teknis acara dimulai dengan registrasi peserta, kemudian acara pembukaan oleh master of ceremony, dilanjutkan dengan pembacaan ayat suci Al Quran, dan pemberian kata sambutan dari pemerintah setempat serta pembukaan acara penyuluhan hukum.

Acara kemudian dilanjutkan dengan pembacaan curriculum vitae dari para pemateri dan pemaparan materi yang disampaikan oleh 4 (empat) orang pemateri, di mana pada akhir materi dibuka sesi tanyajawab.

Setelah itu dilaksanakan FGD untuk memetakan masalah hukum terkait lingkungan hidup yang dialami oleh masyarakat. Setelah terpetanya permasalahan-permasalah hukum yang ada di dalam masyarakat. Selanjutnya dibentuk panel-panel sebagai wadah konsultasi hukum untuk menemukan cara terbaik berkenaan dengan masalah hukum lingkungan yang di maksud.

Setelah berakhirnya panel konsultasi hukum, maka dilakukan penutupan acara disertai dengan pembagian sertifikat dan dilanjutkan dengan acara foto bersama.

\section{HASIL DAN PEMBAHASAN}

Berdasarkan hasil penyuluhan hukum yang dilaksanakan, terdapat beberapa output, antara lain sebagai berikut:

Masyarakat mendapatkan edukasi terkait dengan hak milik berdasarkan ulayat yang selama ini menjadi pokok sengketa dengan hak guna usaha yang dimiliki oleh perusahaan.

Masyarakat mendapatkan pemahaman hukum terkait dengan perkembangan isu lingkungan hidup dalam skala nasional dan terkait pula isu-isu yang bersifat global.

$\begin{gathered}\text { Masyarakat dibekali dengan } \\ \text { pemahaman } \\ \text { dasar terkait }\end{gathered}$
penyelesaian sengketa lahan yang


selama ini menimpa masyarakat. Masyarakat juga diberikan penyadaran berkenaan dengan fungsi, tugas dan peran masyarakat dalam menjaga dan melestarikan lingkungan hidup.

Masyarakat diberikan pemahaman tentang dampak jangka panjang dari kerusakan lingkungan yang akan berikibat akan terjadinya bencana-bencana alam melalui proyeksi yang dilakukan akibat dari rusaknya keseimbangan ekosistem diwilayah hutan gambut pada kawasan Rawa Tripa.

Masyarakat diberikan konsultasi hukum terkait upaya dan langkahlangkah yang dapat ditempuh untuk menyelesaikan masalah hukum terkait lingkungan hidup yang ada ditengah-tengah masyarakat.

Masyarakat diberikan informasi tentang tindak lanjut yang akan dilakukan setelah penyuluhan hukum ini dilaksanakan, yaitu upaya pendampingan hukum yang selanjutnya akan dilakukan oleh para akedemisi dan praktisi LK2BH Teuku Umar.

Di bawah terlampir dokumentasi kegitan penyuluhan hukum yang dilakukan, di mana pada Gambar 1, memuat foto para peserta yang ikut serta dalam kegiatan yang dilakukan. Pada Gambar 2 memuat foto para akademisi universitas teuku umar yang terlibat pada kegiatan tersebut.

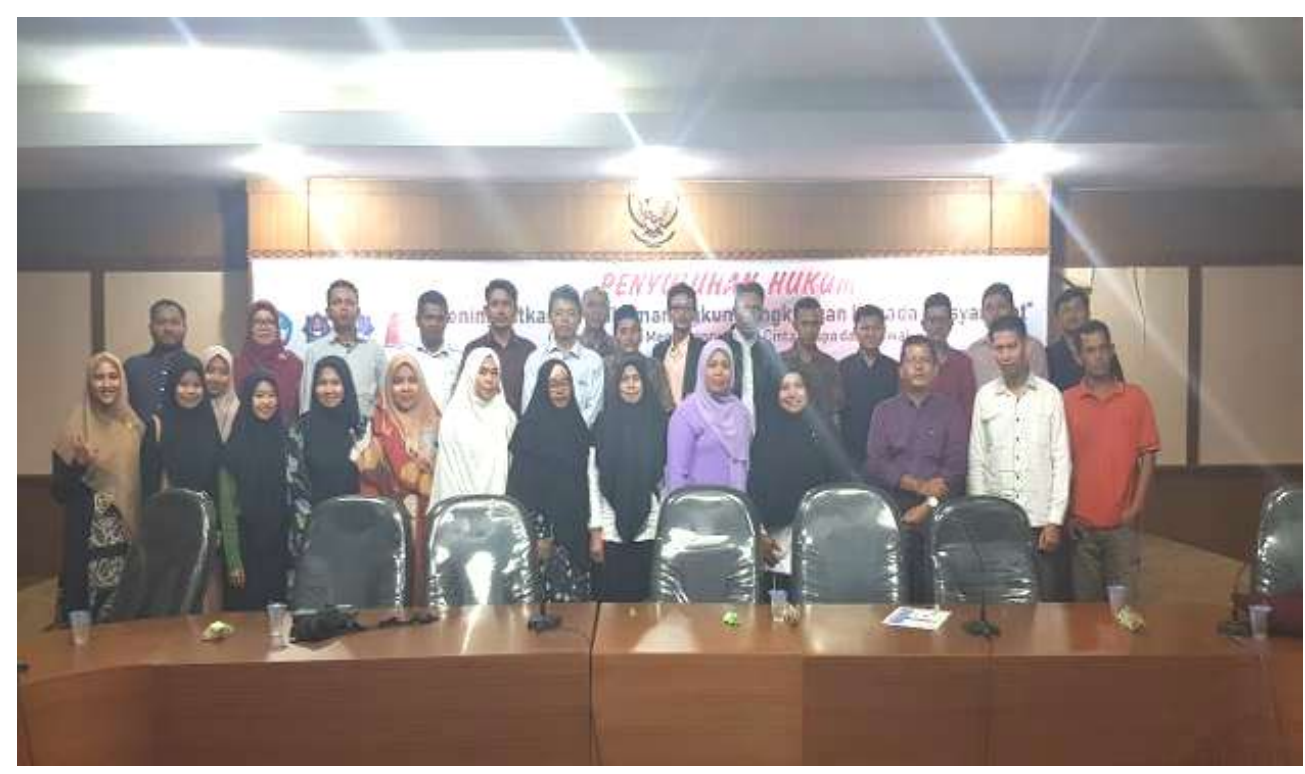

Gambar 1. Penyuluhan Hukum 


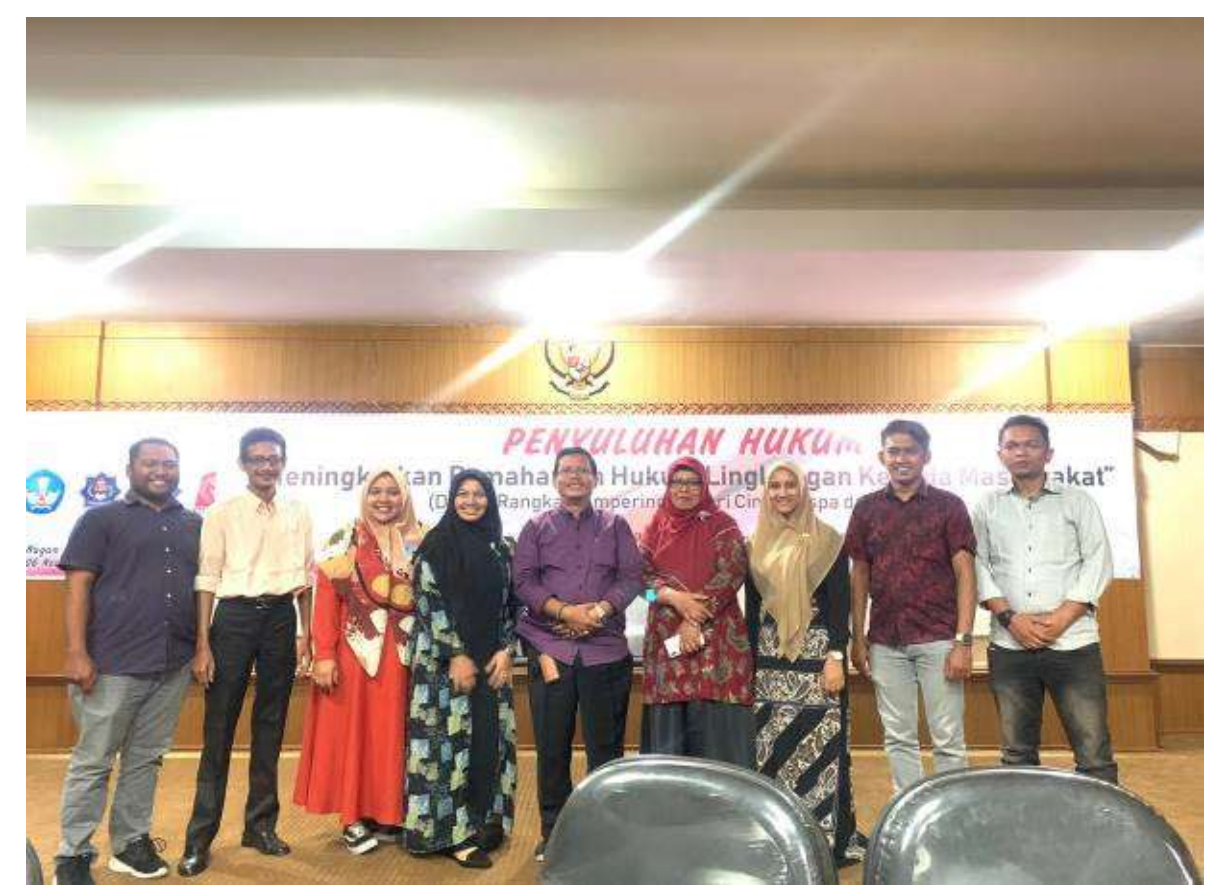

Gambar 2. Penyuluhan Hukum

\section{PENUTUP}

Kegiatan pengabdian kepada masyarakat dalam bentuk penyuluhan hukum dengan tema "Meningkatkan Pemahaman Hukum Lingkungan Hidup Kepada Masyarakat" dapat disimpulkan kepada beberapa poin, antara lain:

Terkait dengan konflik lahan yang terjadi antara masyarakat dan korporasi/perusahaan di dalam kawasan Rawa Tripa Kecamatan Suka Makmur, masih minimnya edukasi dan pemahaman masyarakat tentang sertifikat hak milik lahan yang merupakan payung yuridis pengakuan hak atas tanah terkait kepemilikan hak individual yang diakui oleh negara.

Terjadinya banyak perbuatan melawan hukum yang dilakukan oleh korporasi dalam hal pelaksanaan aktivitas perusahaan seperti pembukaan lahan yang dilakukan dengan pola pembakaran, di mana penerapan pola pembakaran tersebut berdampak langsung pada hancurnya ekosistem dan rusaknya habitat satwa serta berdampak langsung terhadap masyarakat sekitar.

Konflik lahan antara masyarakat dan korporasi merambat kepada persoalan terjadinya banyak intimidasi yang dialami masyarakat dalam mempertahankan haknya.

Dampak dari kerusakan lingkungan di kawasan Rawa Tripa sudah mulai nyata dirasakan oleh $\mathrm{m}$ asyarakat, di mana telah sering terjadi bencana berupa banjir, polusi udara dan permasalahan kesehatan masyarakat dikarenakan 
dampak dari polusi akibat pola pembakaran lahan yang dilakukan oleh pihak korporasi.

Perlu adanya kegiatan-kegiatan penyuluhan hukum lanjutan untuk memupuk kesadaran masyarakat terkait fungsi, tugas, dan peran masyarakat untuk mempertahankan kelestarian lingkungan. Diperlukan pula upaya tindak lanjut untuk mendampingi masyarakat dalam penyelesaian sengketa lahan dengan pihak korporasi.

\section{DAFTAR PUSTAKA}

Fuady, M. (2007). Sosiologi Hukum Kontemporer, Interaksi Kekuasaan, Hukum dan Masyarakat. Bandung: Citra Aditya Bakti.

Soekanto., S. (1986). Berbagai Cara dan Mekanisme Dalam Penyuluhan Hukum. Jakarta: Pradya Paramita.

Soekanto, S. (1982). Kesadarn Hukum dan Kepatuhan Hukum. Jakarta: Rajawali.

Sudjana. (2016). Penyuluhan Hukum Dalam Upaya Peningkatan Kesadaran Hukum Berlalu Lintas Pemahaman Terhadap Isi Undang-Undang Nomor 22 Tahun 2009 Tentang Lalu Lintas Dan Angkutan Jalan. Jurnal Pendidikan Ilmu Sosial (JPIS).

Warasih, E. (2005). Pranata Hukum Sebagai Telaah Sosiologis. Semarang: Suryadaru Utama. 